\title{
三相イミタンス変換器
}

\author{
正 員 入江 寿一 (大阪電気通信大学) \\ 学生員 西浴 貴之（大阪電気通信大学）
}

\section{Three-Phase Immittannce Converter}

\section{Hisaichi Irie, Member \& Takayuki Nishisako, Student Member (Osaka Electro-Communication University)}

\begin{abstract}
The immittance converter has an input impedance that is proportional to the admittance of a load connected across it's output terminals. In this converter, the output current is proportional to the input voltage and the input current is proportional to the output voltage. Consequently a constant voltage source is converted into a constant current source and a constant current source into a constant voltage source. The immitance converters consist of only the passive elements reactor $\mathrm{L}$ and capacitor $\mathrm{C}$ are suitable to use in a high frequency link of power electronics.

We proposed some types of immittance converters and some applications to power electronics equipment. In this paper, we propose a new 3-phase immittance converter consist of each three $\mathrm{L}, \mathrm{C}$ elements to obtain an alternating current source from a 3 phase voltage source without control.

This paper shows the configuration of the new 3-phase immittance converter that operates on either the anti-phase or the in phase between the input voltage and the output voltage, and it's voltage-current transformation characteristics and efficiency characteristics.
\end{abstract}

キーワード:三相，イミタンス変換器，特性インピーダス，効率，電流変動率

Keyword8: 3-phase, immittance converter, characteristic impedance, efficiency, regulation of current

\section{1.まえがき}

イミタンス変換器とはインビーダンス・アドミタンス変 換器の略称で入力電压と出力電流が比例し, 入力電流と出 力電圧が比例するものを言う。イミタンス変換器を用いる と電圧源は容易に電流源に変換できる。共振形のイミタン 不変換器は $\mathrm{L}, \mathrm{C}$ 受動素子のみで構成され, 高効率でパワ 一エレクトロニクスの高周波リンクに用いるのに適して いる。

著者らは数種類のイミタンス変換器とその応用(1),(2)に ついて提案してきたが本論文では三相交流に対して有効 な三相イミタンス変換器を提案する。三相イミタンス変換 器は三相電源の連系, 大電力の定電流源を無制御で得る場 合等に適していると考えられる。

本論文は，入力・出力が逆相または同相で動作するイミ タンス変換器の構成を示し, 変換特性, 効率等の基本特性 について述べる。

\section{2.イミタンス変換器}

図 1 にイミタンス変換器の 1 つである T-LCL 形イミタ ンス変換器を示している。以下, 三相イミタンス変換器と 区別するために単相イミタンス変換器と称する。

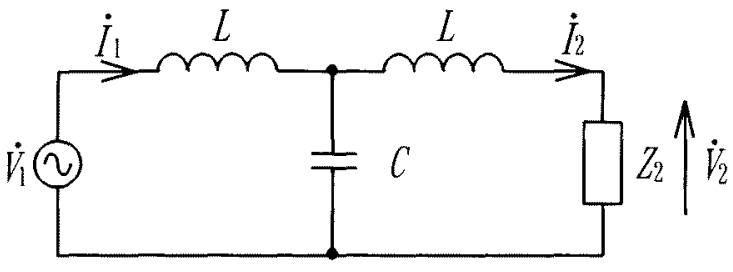

図 1 単相イミタンス変換器

Fig.1. Single-phase Immittance Converter

単相イミタンス変換器を, 共振周波数 $\omega_{r}=1 / \sqrt{L C}$ にお 
ける4端子行列で表すと次式のようになる。

$$
\left[\begin{array}{c}
\dot{V}_{1} \\
\dot{I}_{1}
\end{array}\right]=\left[\begin{array}{cc}
0 & j Z_{0} \\
j / Z_{0} & 0
\end{array}\right]\left[\begin{array}{c}
\dot{V}_{2} \\
\dot{I}_{2}
\end{array}\right]
$$

ただし， $Z_{0}=\sqrt{L / C}$ : 特性インピーダンス

4 端子定数の $\dot{\mathrm{A}}=\dot{\mathrm{D}}=0$ であることがイミタンス変換器の 特徵である。

$$
\left.\begin{array}{l}
\text { 式(1)より } \\
\dot{V}_{1}=j Z_{0} \dot{I}_{2} \\
\dot{I}_{1}=j \frac{1}{Z_{0}} \dot{V}_{2}
\end{array}\right\}
$$

となり, 入力電圧 $V_{1}$ と出力電流 $I_{2}$ が比例し入力電流 $I_{1}$ と 出力電圧 $V_{2}$ が比例する。したがって入力電压 $V_{1}$ が定電压 源で一定電圧あれば，出力電流は $I_{2}$ 一定すなわち定電流 源に変換される。また, 式(2)より入力電王 $V_{1}$ は出力電流 $I_{2}$ より 90 度進み, 入力電流 $I_{1}$ は出力電压 $V_{2}$ より 90 度 進みとなる。

\section{3. 三相イミタンス変換器}

\section{$<3.1>$ 単相イミタンス変換器の三相接続}

図 2 は単相イミタンス変換器 3 個で構成した三相イミ タンス変換器を示している。部品点数は単相イミタンス変 換器の 3 倍必要で, 力率 1 のとき $\mathrm{a}, \mathrm{b}, \mathrm{c}$ 相電圧と $\mathrm{a}^{\prime}, \mathrm{b}^{\prime}$, c’相電圧の位相差は90度となる。

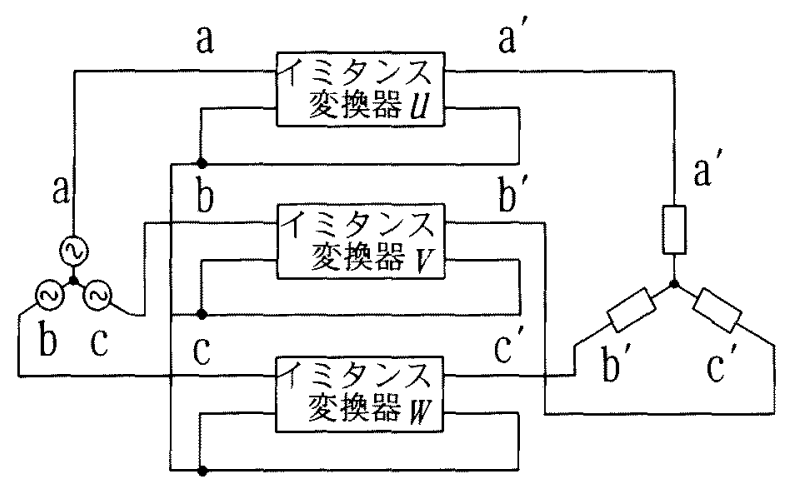

図 2 単相イミタンス変換器 3 個で構成した

$$
\text { 三相イミタンス変換器 }
$$

Fig.2. 3-phese Immittannce Converter that consists of Single-phase Immittance Converters

\section{$<3.2>$ 逆相回路}

図 3(i )に提案する三相イミタンス変換器の回路を示す。

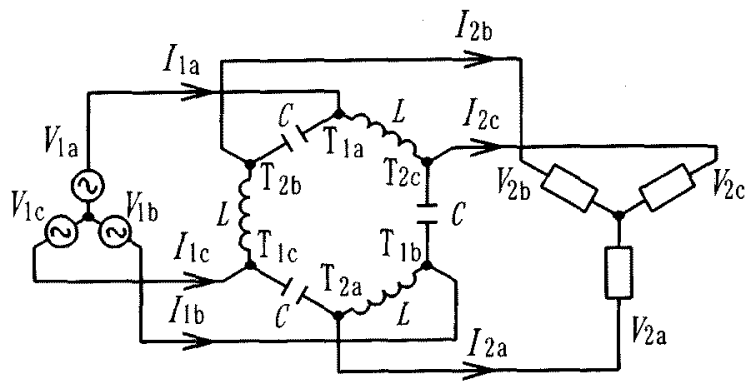

\section{三相電源 三相イミタンス変換器 三相負荷}

(i) 回路図

(i ) circuit
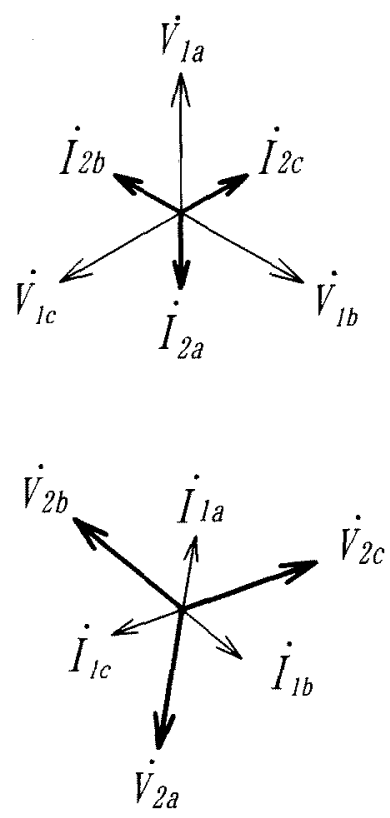

(ii) フェーザ図

(ii) phasors

図 3 三相イミタンス変換器（逆相回路）

Fig.3. 3-phese Immittannce Converter (Anti-phase circuit)

$\mathrm{C}$ は無損失，Lは等洒直列抵抗 $\mathbf{r}$ による損失があるもの と考元る。電源周波数と $L C$ 共振周波数が $\omega_{r}=1 / \sqrt{L C}$ で 一致するならば, 入力と出力の関係は次式の四端子行列で 表される。 


$$
\begin{aligned}
{\left[\begin{array}{c}
\dot{V}_{1 a} \\
\dot{I}_{1 a}
\end{array}\right] } & =\frac{-1}{1-\frac{\alpha}{\sqrt{3} Q}}\left[\begin{array}{cc}
\frac{1}{\sqrt{3} Q} & Z_{0}\left(1-j \frac{1}{Q}\right) \\
\frac{1}{Z_{0}} & \frac{1}{\sqrt{3} Q}
\end{array}\right]\left[\begin{array}{c}
\dot{V}_{2 a} \\
\dot{I}_{2 a}
\end{array}\right] \\
& \cong-\left[\begin{array}{cc}
\frac{1}{\sqrt{3} Q} & Z_{0} \\
\frac{1}{Z_{0}} & \frac{1}{\sqrt{3} Q}
\end{array}\right]\left[\begin{array}{l}
\dot{V}_{2 a} \\
\dot{I}_{2 a}
\end{array}\right] \ldots \ldots .
\end{aligned}
$$

ただし $Z_{0}=\sqrt{L / 3 C}$ : 特性インピーダンス $\alpha=\exp (j 2 \pi / 3), Q=\omega, L / r$

Qが大きいとき 4 端子定数の A と D は 0 となるのでイ ミタンス変換器である。式(3)より入力電圧と出力電流が 比例し, 入力電流と出力電压が比例する。

入力電圧 $V_{1 a}$ と出力電流 $I_{2 a}$, 入力電流 $I_{1 a}$ と出力電压 $V_{2 a}$ は逆相の関係になるのでこの回路を逆相回路と呼ぶこ とにする。電流, 電圧フェーザは図 $3($ ii $)$ となる。 $\dot{I}_{2}$ は $\dot{V}_{1}$ と 逆相となる。 $\dot{V}_{2}$ と $\dot{I}_{2}$ の位相差は負荷の力率で決まる。 $\dot{I}_{1}$ は $\dot{V_{2}}$ と逆相である。

式(3)より $V_{2}, I_{2}$ は，

$$
\left.\begin{array}{l}
V_{2}=Z_{0} I_{1}-\frac{Z_{0}}{\sqrt{3} Q} I_{2} \\
I_{2}=\frac{1}{Z_{0}} V_{1}-\frac{1}{\sqrt{3} Q Z_{0}} V_{2}
\end{array}\right\}
$$

となり, 出力電流 $I_{2}$ と出力電圧 $V_{2}$ は変換項 (第 1 項) と 変動項（第 2 項）に分けて考えることができる。式(4)の 第 2 項の係数はそれぞれ定電圧源の内部抵抗および定電 流源の内部コンダクタンスを表している。

負荷力率 1 のときの効率 $\eta$ は以下の式になる。

$$
\eta=\frac{1}{\frac{1}{\sqrt{3} Q}\left(\frac{Z_{2}}{Z_{0}}+\frac{Z_{0}}{Z_{2}}\right)+1-\frac{1}{\sqrt{3} Q}}
$$

最大効率は $\eta_{\max }$ は $Z_{2}=Z_{0}$ のときに生じ，以下のよう に近似できる。

$$
\begin{aligned}
\eta_{\max } & =\frac{1}{\frac{1}{\sqrt{3} Q}+1} \\
& \cong 1-\frac{1}{\sqrt{3} Q}
\end{aligned}
$$

$Q=100$ のとき最大効率 $\eta_{\max }=99.4 \%$ となり，T-LCL 形 の最大効率(3) $98.0 \%$ よはるか大きく, 効率の高い八イブ リッド形(4)の 99.0\%よりさらに高い効率を持っている。

\section{$<3.3>$ 同相回路}

図 4（ｉ）に示す回路は，図 3 のコンデンサCとリアクト ルLの順序が入れ替わっている。電源の相順序を逆にした と考えてもよい。

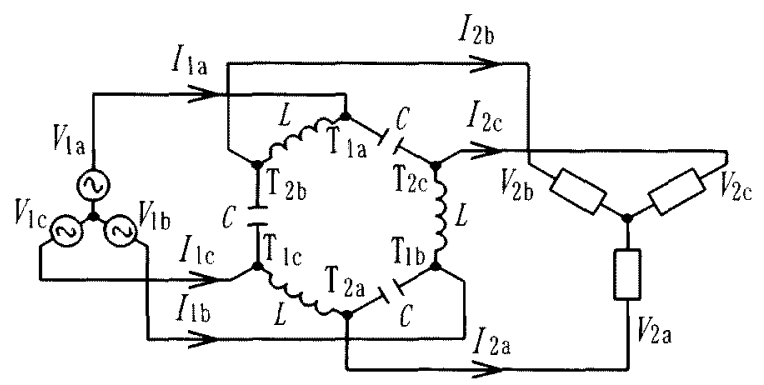

三相電源 三相イミタンス変換器 三相負荷

$$
\text { (i) 回路図 }
$$
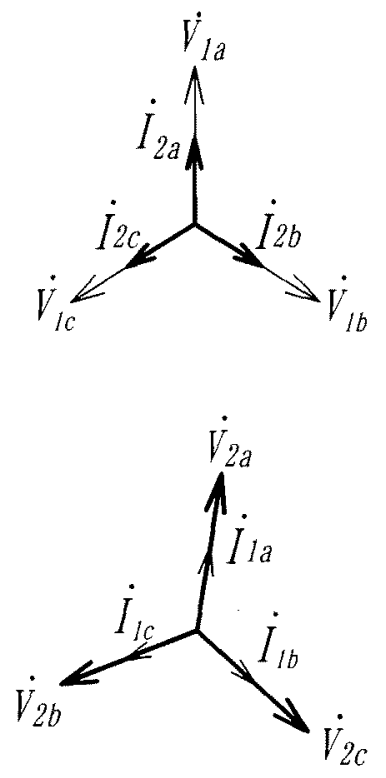

(ii) フェーザ図

(ii) phasors

図 4 三相イミタンス変換器 (同相回路)

Fig.4. 3-phese Immittannce Converter (In-phase circuit)

共振周波数における四端子行列は次式で表される。 


$$
\begin{aligned}
{\left[\begin{array}{c}
\dot{V}_{1 s} \\
\dot{I}_{1 a}
\end{array}\right] } & =\frac{1}{1+\frac{\alpha^{2}}{\sqrt{3} Q}}\left[\begin{array}{cc}
\frac{1}{\sqrt{3} Q} & Z_{0}\left(1-j \frac{1}{Q}\right) \\
\frac{1}{Z_{0}} & \frac{1}{\sqrt{3} Q}
\end{array}\right]\left[\begin{array}{c}
\dot{V}_{2 a} \\
\dot{I}_{2 a}
\end{array}\right] \\
& \cong\left[\begin{array}{cc}
\frac{1}{\sqrt{3} Q} & Z_{0} \\
\frac{1}{Z_{0}} & \frac{1}{\sqrt{3} Q}
\end{array}\right]\left[\begin{array}{l}
\dot{V}_{2 a} \\
\dot{I}_{2 a}
\end{array}\right] \ldots \ldots \ldots \ldots
\end{aligned}
$$

ただし， $Z_{0}=\sqrt{L / 3 C}$ :特性インピーダンス

$$
\alpha=\exp (j 2 \pi / 3), Q=\omega, L / r
$$

$\mathrm{Q}$ が大きいとき 4 端子定数の A と D は 0 上なるのでイ ミタンス変換器である。図 3 の逆相回路と比較すると入力 電压 $V_{1 a}$ と出力電流 $I_{2 a}$, 入力電流 $I_{1 a}$ と出力電圧 $V_{2 a}$ か 同相になる。この回路を同相回路と呼ぶことにする。

電流, 電圧フエーザは図4（ii）に示している。 式(7)より， $V_{2}, I_{2}$ は

$$
\left.\begin{array}{l}
V_{2}=Z_{0} I_{1}-\frac{Z_{0}}{\sqrt{3} Q} I_{2} \\
I_{2}=\frac{1}{Z_{0}} V_{1}-\frac{1}{\sqrt{3} Q Z_{0}} V_{2}
\end{array}\right\}
$$

となり，式(4)と同じ変換特性となる。

効率 $\eta$ は以下式になる。

$$
\eta=\frac{1}{\frac{1}{\sqrt{3} Q}\left(\frac{Z_{2}}{Z_{0}}+\frac{Z_{0}}{Z_{2}}\right)+1+\frac{1}{\sqrt{3} Q}}
$$

式(5)と比較すると分母の第 3 項が正であり, 逆相回路よ り效率泜低い。

最大効率は $\eta_{\max }$ は $Z_{2}=Z_{0}$ のときに生じ, 以下のよう に近似できる。

$$
\begin{aligned}
\eta_{\max } & =\frac{1}{\frac{3}{\sqrt{3} Q}+1} \\
& \cong 1-\frac{3}{\sqrt{3} Q}
\end{aligned}
$$

式(10)より $Q=100$ のき最大効率は $98.3 \%$ となる。

\section{4. 逆相回路と同相回路の比較}

図 5 は, 三相イミタンス変換器の逆相回路と同相回路の, コンデンサCとリアクトルLの電圧・電流フェーザを示し ている。抵抗負荷の場合, 負荷電圧と負荷電流は同相とな
るので，逆相回路では逆相動作，同相回路では同相動作と なる。同じ電源電圧, 負荷電流に対して, 同相動作の方が CとLにかかる電压は大きい。したがって，CとLの素子 電流 $\dot{I}_{C}, \dot{I}_{L}$ も大きい。

出力電流はCししの電流の和である。逆相動作の力が $\dot{I}_{C}, \dot{I}_{L}$ の位相差が小さく，すなわち無効電流が小さい ので効率仗高い。
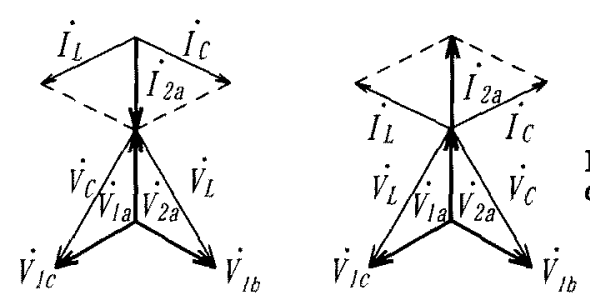

同相動作
In-phase
operation

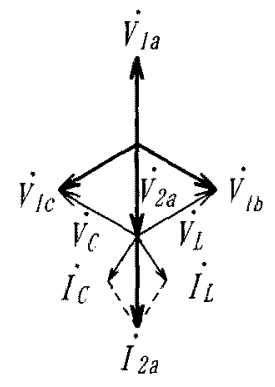

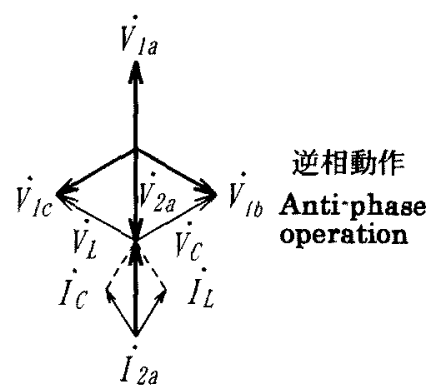

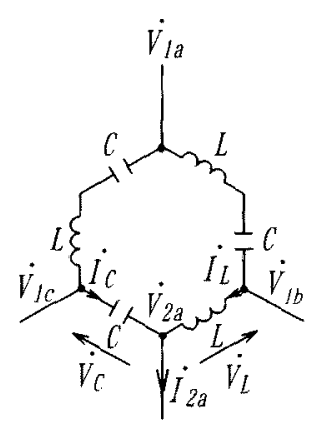

(i) 逆相回路

(i) Ant i-phase circuit

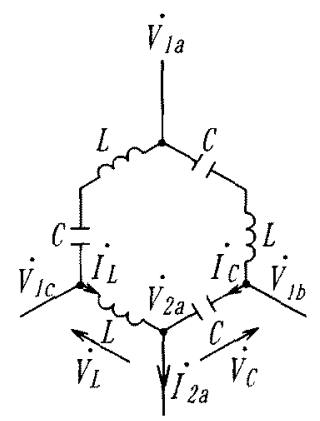

(ii) 同相回路

(ii) In-phase circuit
図 5 コンデンサCとリアクトルLの電压・電流 フェーザ図

Fig.5. Voltage and a current phasor of capacitor $C$ and reactor $L$

\section{5. 電力の制御}

三相イミタンス変換器を通過する電力は

$$
P=3 V_{1} I_{1} \cos \theta
$$

$$
\text { ただし， } \theta \text { : 力率角 }
$$

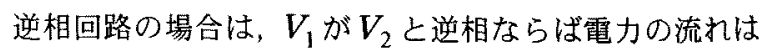


$V_{1} \rightarrow V_{2}$ で

$$
P=-3 \frac{V_{1} V_{2}}{Z_{0}} \cos \theta
$$

であるから， $V_{2}$ または $V_{1}$ を変化することによって電力を 制御でき， $V_{2}$ の極性によって電力潮流の方向も変えられる。 $V_{2}$ の極性を $V_{1}$ 之同相之すれば, 電力の流饥は $V_{2} \rightarrow V_{1}$ にす ることができる。 $V_{1}, V_{2}$ の位相は逆相のままで， $\mathrm{L}, \mathrm{C} の$ 接続を変えて，同相回路とし，電力潮流を $V_{2}$ 側 $\rightarrow V_{1}$ 側と する方が効率は高い。表 1 に逆相，同相回路と $V_{1}, V_{2}$ の 位相による電力潮流を示している。

表 1 電力潮流

Table 1. Power flow

\begin{tabular}{|c|c|c|}
\hline 回路 & $\begin{array}{c}\text { 逆相回路 } \\
V_{1} ， I_{2}: \text { 逆相 } \\
V_{2}, I_{1} \text { : 逆相 }\end{array}$ & $\begin{array}{c}\text { 同相回路 } \\
V_{1}, I_{2}: \text { 同相 } \\
V_{2}, I_{1} \text { : 同相 }\end{array}$ \\
\hline $\begin{array}{c}\text { 逆相動作 } \\
V_{1}, V_{2}: \text { 逆相 }\end{array}$ & $V_{1} \rightarrow V_{2}$ & $V_{1}-V_{2}$ \\
\hline $\begin{array}{c}\text { 同相動作 } \\
V_{1}, V_{2} \text { : 同相 }\end{array}$ & $V_{1} \leftarrow V_{2}$ & $V_{1} \rightarrow V_{2}$ \\
\hline
\end{tabular}

図6は図 3 の逆相回路の三相負荷端子に三相電源 $V_{1 a}$, $V_{1 b}, V_{1 c}$ と同一周波数の別電源 $V_{2 a}, V_{2 b}, V_{2 c}$ 娄接続 したものである。逆相回路であるから $I_{2}$ は $V_{1}$ と逆相であ る。 $V_{1}$ と $V_{2}$ が逆相であれば抵抗負荷と同様で電力の流れ は $V_{1}$ 側から $V_{2}$ 側である。負荷の起電力 $V_{2}$ が電源電圧 $V_{1}$ 之同相であると, 電源電流 $I_{1}$ の方向は負荷電圧 $V_{2}$ の極性 で決まるので電源電圧 $V_{1}$ とは逆相になる。したがって電 源梳供給電力が負に変わって電力を吸収し, 負荷は電力が 負になるから電力を放出する。すなわち，電力の流れは負 荷側から電源側 $V_{2} \rightarrow V_{1}$ となる。

連系リアクトルの場合と異なり，電压の極性および大き さで電力の流扎を制御できる。

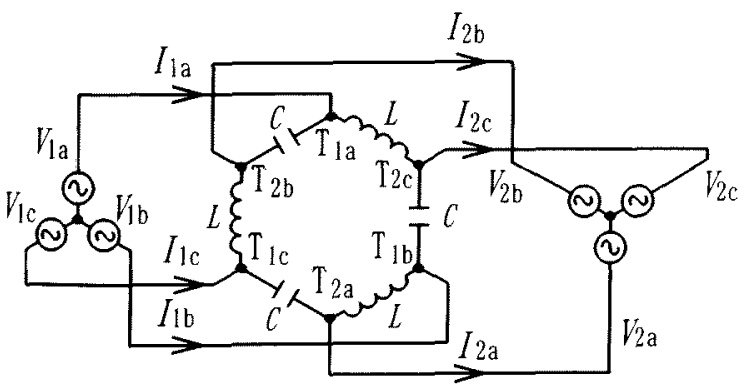

三相電源 三相イミタンス変換器 三相負荷

図 6 三相イミタンス変換器（系統連系）

Fig.6. 3-phese Immittannce Converter (Interactive connection)

\section{6. 特性計算}

図 3,4 の三相イミタンス変換器に抵抗負荷を接続し, 共振周波数の定電圧を入力したときの特性を図 7,8 に示 している。入力に $V_{1}=30 \mathrm{~V}$ を加え，リアクトルの Lの Q を $\mathrm{Q}=100, Z_{0}=10 \Omega$ とし, 負荷インピーダンス $Z_{2}$ を特性 インピーダンス $Z_{0}$ の 0 3 倍の $30 \Omega$ まで変化させている。 図中害線牥計算値,マークはシミュレーション結果である。

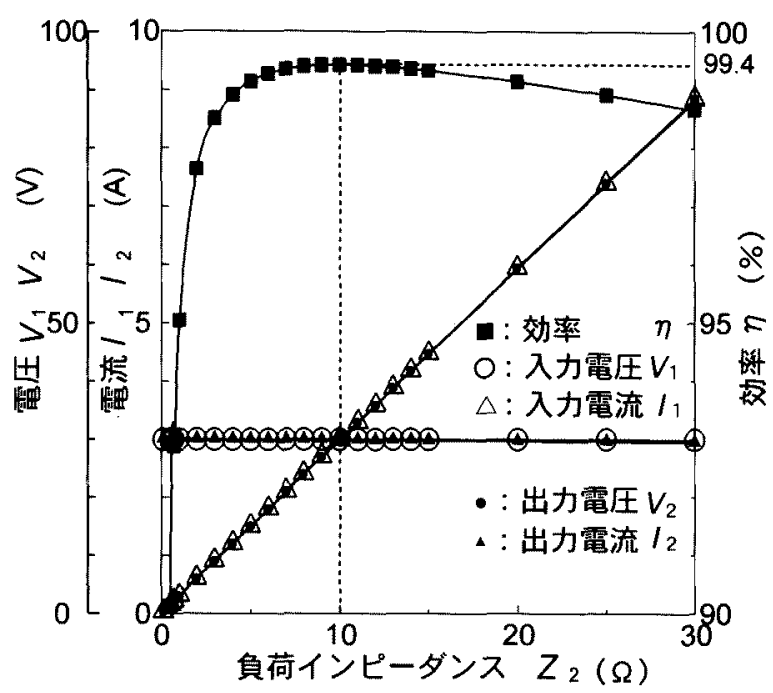

図 7 出力特性 (逆相回路および同相回路の逆相動作)

Fig.7. Output characteristics

(Anti-phase operation of Anti- and In-phase circuit)

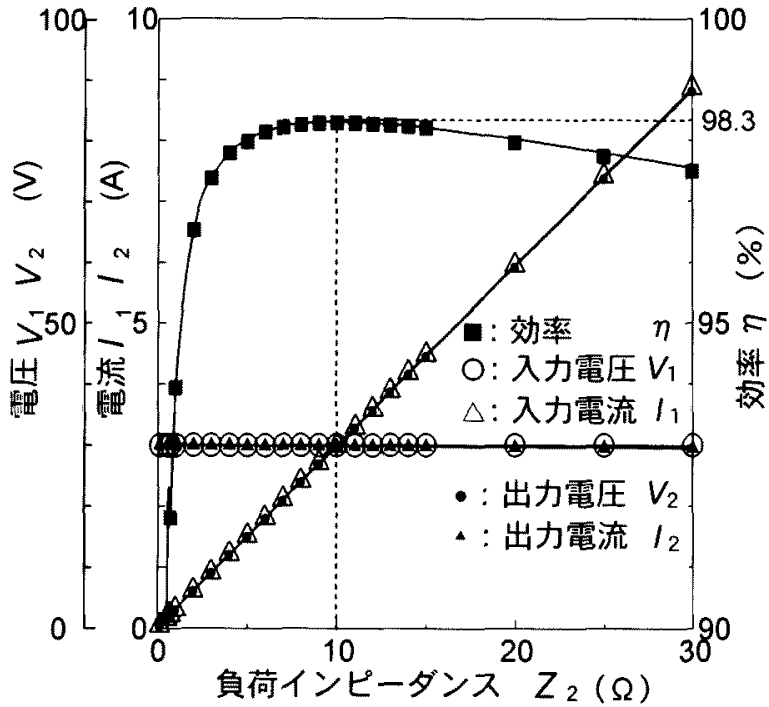

図 8 出力特性（同相回路および逆相回路の同相動作）

Fig.8. Output characteristics

(In-phase operation of In- and Anti-phase circuit) 
図 7 は式(4), (5)による逆相回路の特性で, 同相回路で も逆相動作のときはこの特性になる。図 8 は式(8), (9)に よる同相回路の特性で, 逆相回路でも同相動作のときはこ の特性になる。計算結果とシミュレーション結果である。

図 7,8 より一定電压 $30 \mathrm{~V}$ を力したときは負荷インピ 一ダンスを変化しても出力電流は $3 \mathrm{~A}$ 一定となっている。 入力電圧は出力電流に比例し, 入力電流と出力電圧が比例 している。

電压・電流変換率は特性インピーダンス $Z_{0}$ で決まる。 出力電流変動率は $Z_{0}$ と $Q$ で決まり, 内部抵抗の計算值は $1730 \Omega$ で, 負荷抵抗 $0 \sim 30 \Omega$ 電流変動率は $1.7 \%$ あ゙る。

効率は逆相動作と同相動作で異なる。逆相動作は非常に 高い効率を持っており $Q=100$ のとき $99.4 \%$ ある。同相 動作では約 $1.1 \%$ 低い。

\section{7. むすび}

提案した三相イミタンス変換器は単相イミタンス変換 器 3 個で構成するより, 部品点数を減少することができる。 三相イミタンス変換器は, 負荷電圧に影響されずに定電 圧入力が定電流出力になる。

提案した三相イミタンス変換器には電圧逆相と電圧同 相の動作があり, 変換特性は同じであるが, 効率は異なる。

負荷電圧を正から負まで連続的に変化すれば, イミタン ス変換器を通過する電力は正から負まで連続的に变化す ることができる。

効率は $Q=100$ のとき逆相動作では出力電圧が入力電圧 の $1 / 2 \sim 2$ 倍で $99 \%$ 以上なり, 最大効率は $99.4 \%$ となる。 同相動作では同じ条件で効率が $98 \%$ 以上となり, 最大効 率は $98.3 \%$ となる。

提案した三相イミタンス変換器は, ある機能を持った回 路としては非常に高い効率を持っていると言えるであろ う。しかし， $50,60 \mathrm{~Hz}$ の低周波三相交流に対しては L, $\mathrm{C}$ のインダクタンス, 静電容量が大きくなりすぎる問題点 はある。

提案した三相イミタンス変換器は線間電圧から相電流 を得る回路構成になっているので, 不平衡三相の電源に対 して問題なく動作すると考えられる。

電源電圧に含まれる高調波の影響は, 詳細は未検討であ るが線形回路であるから重ね合わせの定理が適用できる であろう。すなわち, 基本波は電圧-電流変換されて定電 流源となり, 高調波は容量結合でほぼ定電圧源になると考 えられる。

(平成 13 年 5 月 21 日受付, 平成 14 年 1 月 4 日再受付)

\section{参考文献}

（1）山名, 入江：「イミタンス変換を使用した電力変換装 置」平成 8 年電気学会全国大会, No.817(1996)

(2) 入江, 山名:「パワーエレクトロニクスに適するイミ タンス変換器」電学学会論文誌, $117-\mathrm{D}, 8,962-969$ (1997)

（3）大西, 入江, 櫻井, 山名:「イミタンスコンバータの 効率特性」, 平成 10 年電気学会産業応用部門大会, No. 215

(4) 入江, 川端：「ハイブリッド形イミタンス変換器の効 率特性」, 電気学会論文誌, $121 \cdot \mathrm{D}, 1 ， 119 \cdot 124(2001)$

（5）西浴貴之・入江寿一:「三相イミタンス変換器の構成」, 平成 12 年電気関係学会関西支部連合大会, G4-21

（6）西浴貴之·入江寿一:「三相イミタンス変換器の効率」, 平成 13 年電気学会全国大会, 4-093

入江 寿一（正員）1937年4月21日生。1960年3月大 阪府立大学工学部電気工学科卒業。同年 4 月シャープ(俐入社。1964年大阪府立大学工 学部電気工学科助手, 助教授。1990年 4 月 大阪電気通信大学工学部電子機械工学科教 授。DCチョッパ等半導体電力変換回路およ び電動機駆動, ソフトスイッチング等の研 究に従事。工学博士。1995年著作賞受賞。計測自動制御学 会, システム制御情報学会, パワーエレクトロニクス研究 会, I E E E 会員。

西浴 貴之（学生員）1976 年 8 月 28 日生。2000年 3 月大阪電気通信大学工学部電子機械工学科 卒業。同年 4 月, 同大学大学院工学研究科 制御機械工学専攻入学。現在に至る。 